\title{
Heterotrophic Bacteria Show Weak Competition for Nitrogen in Mediterranean Coastal Waters (Thau Lagoon) in Autumn
}

\author{
Trottet Aurore ${ }^{1,3,5}$, Leboulanger Christophe 1, 2,3, Vidussi Francesca 1, 2, 4 , Pete Romain ${ }^{1,2}$, \\ Bouvy Marc ${ }^{1,2,4}$, Fouilland Eric ${ }^{1,2,3,{ }^{*}}$
}

${ }^{1}$ Univ Montpellier I, Univ Montpellier 2, CNRS IRD IFREMER, ECOSYM,Lab Ecol Syst Marins Cotiers,UMR 5119, Montpellier, France.

${ }^{2}$ CNRS UM IRD IFREMER, MARBEC, UMR 9190, Montpellier, France.

${ }^{3}$ Stn Marine Environm Littoral, 2 Rue Chantiers, F-34200 Sete, France.

${ }^{4}$ Univ Montpellier, PI E Bataillon,CC 093, F-34095 Montpellier, France.

${ }^{5}$ DHI Water Environm S Pte Ltd, 1 Cleantech Loop 03-05 CleanTech 1, Singapore 637141, Singapore.

Corresponding author : Eric Fouilland, email address : eric.fouilland@cnrs.fr

\begin{abstract}
:
The importance of heterotrophic bacteria relative to phytoplankton in the uptake of ammonium and nitrate was studied in Mediterranean coastal waters (Thau Lagoon) during autumn, when the Mediterranean Sea received the greatest allochthonous nutrient loads. Specific inhibitors and sizefractionation methods were used in combination with isotopic $\mathrm{N}-15$ tracers. NO3 (-) and $\mathrm{NH} 4(+)$ uptake was dominated by phytoplankton (60\% on average) during the study period, which included a flood event. Despite lower biomass specific $\mathrm{NH} 4(+)$ and $\mathrm{NO} 3$ uptake rates, free-living heterotrophic bacteria contributed significantly (> $30 \%)$ to total microbial $\mathrm{NH} 4(+)$ and $\mathrm{NO} 3(-)$ uptake rates in low chlorophyll waters. Under these conditions, heterotrophic bacteria may be responsible for more than $50 \%$ of primary production, using very little freshly produced phytoplankton exudates. In low chlorophyll coastal waters as reported during the present 3-month study, the heterotrophic bacteria seemed to depend to a greater extent on allochthonous $\mathrm{N}$ and $\mathrm{C}$ substrates than on autochthonous substrates derived from phytoplankton.
\end{abstract}

Keywords : Bacteria, Phytoplankton, Inhibitors, Size fractionation, Nitrogen uptake, Dissolved inorganic nitrogen 


\section{Introduction}

The abundance and distribution of microorganisms in aquatic ecosystems depend on how they adapt to changes in environment (e.g. variations in nutrients, light and temperature) as well as on trophic interactions such as prey-predator relationships and resource competition. Heterotrophic bacteria, heterotrophic archaea and phytoplankton (including unicellular cyanobacteria) constitute the base of the marine food webs and can be considered as essential for the biogeochemical cycling of dissolved elements, carbon cycling and energy transfer [18]. Phytoplankton are generally considered to be the main user of dissolved inorganic nutrients whereas heterotrophic bacteria are assumed to play only a minor role. However, increasing evidence suggests that heterotrophic bacteria do not only mineralize dissolved organic nitrogen (DIN: $\mathrm{NO}_{3}{ }^{-}$and $\mathrm{NH}_{4}{ }^{+}$) into inorganic forms but that they also require a direct inorganic nitrogen supply for their own growth $[3,18,40]$. It has been recognized that heterotrophic bacteria assimilate DIN to meet growth requirements not fulfilled by organic substrates [18]. Heterotrophic bacterial assimilation of DIN in estuarine and marine systems has been reported to account for a significant but widely variable fraction $(<5 \%$ to $>90 \%)$ of total DIN uptake $[1,19,22,23]$. A high heterotrophic bacterial contribution to the total $\mathrm{NO}_{3}^{-}$uptake rates was reported in various marine ecosystems having low chlorophyll a ( $\mathrm{Chl}$ a) concentrations [10]. Based on these observations, two opposing hypotheses were postulated i) heterotrophic bacteria outcompete primary producers for DIN in low chlorophyll waters and ii) heterotrophic bacteria are weak competitors for DIN compared to phytoplankton and contribute strongly to DIN uptake only when phytoplankton is limited by factors other than nutrient availability.

This study was designed to assess the contribution of heterotrophic bacterial to DIN uptake rates in coastal waters characterized by large variations in both inorganic and organic nutrient concentrations and microbial production [13]. In a Mediterranean climate, coastal ecosystems such as the Thau Lagoon are subject to long dry periods interrupted by rainfall events of short duration associated with high levels of runoff. As a consequence, the Thau Lagoon regularly receives river discharges, occurring mainly during the autumn [4], which implies high nitrogen loads in the lagoon during this period [29, 33]. This study was based on the DIN uptake rates in the Thau Lagoon, measured using specific inhibitors as described by Trottet et al. [35], during the autumn 2008, including a flood event. This flood event occurred from 1 to 17 November, and was generated by a large storm followed by a 
series of five rain showers [13]. The total flood load measured at the outlet of the river Vène draining the largest catchment area $\left(67 \mathrm{~km}^{2}\right)$ was $5.5 \mathrm{Mm}^{3}$ which represented about $2 \%$ of the total volume of water in the lagoon [13]. Over half the total nitrogen, phosphorus, silicate and dissolved organic carbon load was discharged from the river Vène into the Thau Lagoon within the first five days of the flood event. Such loads represent about $8 \%$ and $3 \%$ of the average yearly total nitrogen and phosphorus load discharged into the Thau Lagoon, respectively [13]. This is a moderate contribution as one river flood event may contribute to more than $15 \%$ of the total annual nitrogen inputs into the lagoon [33]. As a direct consequence, the nitrate uptake rate increased by three orders of magnitude at the end of the flood period (from 0.007 to $0.3 \mu \mathrm{g} \mathrm{N} \mathrm{L}^{-1} \mathrm{~h}^{-1}$ ), and a substantial increase in primary production (PP) was also observed (from 2.6 to $7.0 \mu \mathrm{g} \mathrm{C} \mathrm{L}^{-1} \mathrm{~h}^{-1}$ ). In addition to the use of specific inhibitors, the DIN uptake rates were also measured in these surface waters using size fractionation to exclude cyanobacteria from the estimate of the heterotrophic DIN uptake presented below. The relative importance of phytoplankton and heterotrophic bacteria in the DIN uptake is then discussed in terms of community diversity, biomass specific DIN uptake rates and carbon production during a typical autumn in a Mediterranean climate.

\section{Materials and Methods}

Sampling location

The Thau Lagoon is a shallow lagoon ( $4 \mathrm{~m}$ depth on average) with an area of $75 \mathrm{~km}^{2}$ located on the French Mediterranean coast $\left(43^{\circ} 24^{\prime} \mathrm{N}-3^{\circ} 36^{\prime} \mathrm{E}\right)$, connected to the sea by narrow channels (Fig. 1$)$. The main economic value of this lagoon is oyster and mussel production [5].

Samples were taken from the Crique de l'Angle, a semi-closed embayment $\left(43^{\circ} 27 \mathrm{~N}-3^{\circ} 40 \mathrm{E}\right.$, hereinafter referred to as the Creek station). The Creek station (Fig. 1) receives input from the river Vène, one of the main sources of continental inputs (nutrients, chemical and biological contaminants) during flood events in the Thau Lagoon basin [27, 33]. The station was sampled weekly between 11 September and 12 November 2008. All samples were collected between 08.00 and 09.00 (local time) close to the surface $(0.5 \mathrm{~m}$ depth) using acid-cleaned $10 \mathrm{~L}$ carboys and stored in darkness before 
treatment. Within two hours after sampling, sub-samples were taken to measure the nutrient concentrations, microbial abundance and diversity, nitrogen uptake rates and carbon production of both bacterial and phytoplankton communities. The temperature and salinity of the surface waters were determined in situ during sampling using a WTW multiparametric probe. The daily global, direct and diffuse solar radiation was recorded at the Météo-France station at Fréjorgues airport (20 km from the study site).

Ammonium, nitrate and phosphate concentrations

Triplicate subsamples $(250 \mathrm{~mL})$ were immediately filtered through Whatman GF/F glass-fibre filters. The nitrate concentration in the filtrate was measured using an LS 45 PerkinElmer spectrofluorimeter using a standard method [32] and the ammonium concentration was measured by fluorometry [17]. On certain occasions during the study period, the phosphate concentration in the filtrate was also measured using an automated colorimeter (Skalar) using a standard nutrient analysis method [34].

Phytoplankton and bacterial cell abundance

The nanophytoplankton, picophytoplankton (including cyanobacteria) and heterotrophic bacteria were sampled daily, immediately stored in liquid nitrogen, and enumerated on $2 \%$ (final v:v) buffered formalin fixed subsamples $(1.8 \mathrm{~mL})$. Analyses were performed using a FACSCalibur flow cytometer (Becton Dickinson, San Jose, Ca) with an air-cooled argon laser (488 nm, $15 \mathrm{~mW}$ ). For each analysis, fluorescent beads ( 1 and $2 \mu \mathrm{m}$, YG, Fluoresbrites Polysciences Inc., Warrington, PA) were added to calibrate the flow cytometer. Heterotrophic bacterial cells were stained for 15 min in the dark at $4^{\circ} \mathrm{C}$ with SYBR-Green I (Molecular Probes). TruCount control beads (Becton Dickinson) were added to each sample (bacteria or phytoplankton) to determine the volumes analyzed. The results were collected and analyzed using Cell Quest Pro software (Becton-Dickinson). 
Detection of phytoplankton pigments

Samples $(0.5 \mathrm{~L})$ were filtered onto glass fibre filters (Whatman GF/F), and the filters were stored in liquid nitrogen prior to analysis to improve the extraction efficiency and minimize pigment degradation. Samples were extracted in $2 \mathrm{~mL}$ of $95 \%$ methanol $(1 \mathrm{~h})$, then disrupted by sonication for a few seconds in an ice bath, extracted for an additional hour and then clarified using $0.2-\mu \mathrm{m}$ filters (Millipore) as detailed in Vidussi et al. [39].

Chlorophyll and carotenoid concentrations were analysed using high performance liquid chromatography (HPLC) using a modified version of the method described by Zapata et al. [42] and the HPLC system (WATERS) described by Vidussi et al. [39]. The chlorophylls and carotenoids were identified according to their retention times and absorbance spectra obtained using a photodiode array. The HPLC was calibrated using commercial standards (DHI Denmark and Sigma). Major taxonomic pigments were used as taxonomic markers of major phytoplankton groups. Chlorophyll a $(\mathrm{Chl} a)$ indicated the total phytoplankton biomass. Chlorophyll $b(\mathrm{Chl} b)$ was attributed to green flagellates" (chlorophytes plus prasinophytes). Fucoxanthin (fuco) was mainly attributed to diatoms. 19' hexanoyloxyfucoxanthin (19'HF) indicated the presence of prymnesiophytes. Peridinin (peri) indicated peridinin-containing dinoflagellates. Alloxanthin (allo) indicated cryptophytes. Zeaxanthin (zea) was mainly attributed to cyanobacteria and allowance was made for the contribution of green flagellates" to this pigment.

The relative contribution of the taxonomic groups to total $\mathrm{Chl}$ a, was estimated using the $\mathrm{Chl} a$ to pigment marker ratios reported in the literature $[21,38]$ as follows: diatoms ( $\mathrm{Chl}$ a:fuco $=1.07$ ), cyanobacteria $(\mathrm{Chl}$ a:zea $=1.13)$, cryptophytes $(\mathrm{Chl}$ a:allo $=1.17)$, green flagellates" $(\mathrm{Chl} a: \mathrm{Chl} b=$ 0.70), prymnesiophytes $(\mathrm{Chl}$ a:19'HF $=0.68)$ and dinoflagellates $(\mathrm{Chl}$ a:peri $=0.94)$. It should be noted that $\mathrm{Chl}$ a to pigment marker ratios can vary depending on the species and environmental conditions and that some pigment markers cannot be assigned exclusively to a single group. Therefore, the relative contribution of taxonomic groups as computed here must be considered only as a first approximation and not as an accurate quantification of the taxonomic groups. 
Dissolved inorganic nitrogen uptake rates by phytoplankton and bacteria

Net nitrogen uptake rates ( $\mathrm{N}$ uptake rates) by phytoplankton and bacteria in the surface waters of the Thau Lagoon were assessed using stable isotope tracers [7] with and without specific inhibitors and size fractionation. The procedure using specific inhibitors was described and assessed by Trottet et al. [35]. Surface water samples were collected using $10 \mathrm{~L}$ acid-cleaned polycarbonate bottles. Prokaryotic inhibitors were used to estimate phytoplankton uptake (mixture of streptomycin and penicillin: SP) and a eukaryotic inhibitor was used to estimate total bacteria uptake (cycloheximide: $\mathrm{CHI}$ ). The inhibitors (SP or $\mathrm{CHI}$ ) in powder form were weighed to give a final concentration of $100 \mathrm{mg}$ $\mathrm{L}^{-1}$ for each inhibitor and were first mixed with a $10 \mathrm{~mL}$ sub-sample and shaken vigorously for 1-2 minutes in order to encourage dissolution before being added to $0.5 \mathrm{~L}$ polycarbonate bottles for each $\mathrm{N}$-treatment (3 bottles for $\mathrm{NH}_{4}{ }^{+}$and 3 bottles for $\mathrm{NO}_{3}{ }^{-}$). The bottles with inhibitors were then incubated in the surface waters for $2 \mathrm{~h}$ at the same time as three control bottles without inhibitors (CONT). Three other bottles $(0.5 \mathrm{~L})$ without inhibitors were also incubated for subsequent size fractionation to determine uptake rates for $<0.8 \mu \mathrm{m}$ bacteria only $(\mathrm{BACT}<0.8)$.

After $2 \mathrm{~h}$ of in situ incubation, either $\mathrm{K}^{15} \mathrm{NO}_{3}$ or $\left({ }^{15} \mathrm{NH}_{4}\right)_{2} \mathrm{SO}_{4}$ (final concentration of $0.05 \mu \mathrm{mol} \mathrm{N} \mathrm{L}{ }^{-1}$ ) was added to each bottle. All the bottles were then incubated in the surface lagoon waters close to the shore, hanging on the MEDIMEER Pontoon $\left(43^{\circ} 24^{\prime} 53.03^{\prime \prime} \mathrm{N}, 3^{\circ} 41^{\prime} 16.34 " \mathrm{E}\right)$ under natural light for $4 \mathrm{~h}$ around midday. At the end of incubation, all the samples, except for the three bottles to be used for size fractionation, were filtered onto precombusted Whatman GF/F filters and stored at $-80{ }^{\circ} \mathrm{C}$ until analysis. The samples used for size fractionation were first filtered through $0.8 \mu \mathrm{m}$ Nuclepore filters and then onto precombusted GF/F Whatman filters. The precombusted GF/F filters had an average pore size of about $0.3 \mu \mathrm{m}$ owing to the compaction of the borosilicate glass microfibres during combustion [26]. Only the GF/F filters were stored at $-80^{\circ} \mathrm{C}$ until analysis for the estimation of $\mathrm{N}$ uptake by free-living bacteria $(B A C T<0.8)$. To assess the efficiency of size fractionation in selecting only the free-living bacterial community, the cell abundance of bacteria and picophytoplankton was enumerated in the sample before filtration and in the filtrates after $0.8 \mu \mathrm{m}$ filtration and after GF/F filtration using flow cytometry as described above.

To assess the potential ammonium and nitrate regeneration occurring during the ${ }^{15} \mathrm{~N}$ incubation period, the concentrations of ammonium and nitrate were also measured after filtration onto GF/F 
filters performed using the CONT bottles. These concentrations were then compared with those measured before incubation (see above) using the same analytical protocols.

All the GF/F filters were dried at $60^{\circ} \mathrm{C}$ for $24 \mathrm{~h}$, pelleted and analysed for ${ }^{15} \mathrm{~N}:{ }^{14} \mathrm{~N}$ isotope ratios and particulate organic nitrogen (PON) using an ANCA mass spectrometer (Europa Scientific). The net nitrogen uptake rates $\left(\mu \mathrm{gN} \mathrm{L}^{-1} \mathrm{~h}^{-1}\right)$ were calculated using the equation described by Dugdale and Wilkerson [7], assuming negligible $\mathrm{N}$ regeneration (no isotope dilution) during the 4 hours of incubation. This assumption was verified from the decrease in $\mathrm{NH}_{4}{ }^{+}$and $\mathrm{NO}_{3}^{-}$concentrations measured during incubation without inhibitors (CONT). For all the size-fractionated samples obtained after $0.8 \mu \mathrm{m}$ filtration, a known amount of carrier (56 $\mu \mathrm{g} \mathrm{N}$ and $107 \mu \mathrm{g} \mathrm{C}$ from glycine) was added to each pelletised filter to produce total $\mathrm{N}$ and $\mathrm{C}$ masses sufficiently higher than the mass spectrometer detection limit for reliable ${ }^{15} \mathrm{~N}$ and ${ }^{13} \mathrm{C}$ atom percent enrichment values. A carrier correction was applied when calculating the final ${ }^{15} \mathrm{~N}$ and ${ }^{13} \mathrm{C}$ isotopic enrichment. Biomass specific $\mathrm{NH}_{4}{ }^{+}$and $\mathrm{NO}_{3}{ }^{-}$ uptake rates for phytoplankton and free-living heterotrophic bacteria were estimated from the $\mathrm{NH}_{4}{ }^{+}$ and $\mathrm{NO}_{3}^{-}$uptake rates divided by the biomass and expressed in $\mathrm{h}^{-1}$, using a C:Chl a ratio of 50 , a conversion factor of $20 \mathrm{fgC} \mathrm{cell}^{-1}$ for bacterial cells and phytoplankton and bacterial biomass C:N ratios of 7 and 5 , respectively (see [13]).

Primary and heterotrophic bacterial production

The heterotrophic bacterial production (BP) was estimated from the DNA synthesis rates measured by $\left({ }^{3} \mathrm{H}\right.$ methyl) thymidine $\left({ }^{3} \mathrm{H}-\mathrm{TdR}\right)$ incorporation. A microcentrifuge method was used for separation [31] as described in detail by Fouilland et al. [13]. Results were expressed in $\mu \mathrm{g} \mathrm{C} \mathrm{L}^{-1} \mathrm{~h}^{-1}$

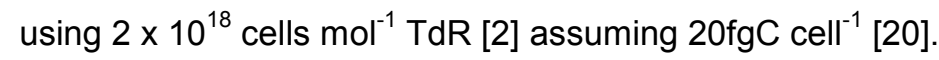

The particulate PP was estimated from the net carbon uptake rates using the ${ }^{13} \mathrm{C}$ tracer method [7] combined with ${ }^{15} \mathrm{~N}$ measurements as described above. Sodium ${ }^{13} \mathrm{C}$-bicarbonate solution $\left(99 \%{ }^{13} \mathrm{C}\right)$ was added to the ${ }^{15} \mathrm{NH}_{4}{ }^{+}$and ${ }^{15} \mathrm{NO}_{3}{ }^{-}$in the control bottles without inhibitors (CONT) and in the bottles

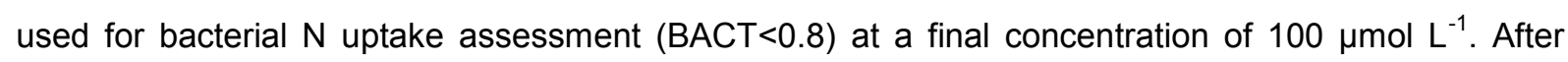
incubation the samples were processed as described for ${ }^{15} \mathrm{~N}$. The ${ }^{13} \mathrm{C}:{ }^{12} \mathrm{C}$ ratio and particulate organic carbon (POC) were measured simultaneously as for ${ }^{15} \mathrm{~N}$ and PON. The carbon uptake rates $\left(\mu \mathrm{g} \mathrm{C} \mathrm{L}^{-1}\right.$ $\mathrm{h}^{-1}$ ) were calculated using the equation given by Dugdale and Wilkerson [7]. The total dissolved 
inorganic carbon was estimated from salinity measurements as described by Strickland and Parsons [32]. The fraction of BP supported by the freshly produced phytoplankton exudates was estimated from the ratio of size-fractionated $(\mathrm{BACT}<0.8) \mathrm{C}$ uptake rates to $\mathrm{BP}$ and expressed in \%. This fraction is probably underestimated as $C$ uptakes rates measured from BACT $<0.8$ samples excluded large bacteria attached to particles and small bacteria not retained by GF/F filters.

Statistical analysis

Spearman correlations were performed on $\log _{10}$-transformed variables. The correlation was tested for significance at $p<0.05$ and $p<0.01$. Spearman correlation matrices were calculated using the $\mathrm{R}$ (www.r-project.org) Hmisc and vegan packages. The Wilcoxon signed rank test was performed in order to compare values of biomass specific $\mathrm{N}$ uptake rates measured for phytoplankton and heterotrophic free-living bacteria with significant difference when $p \leq 0.05$.

\section{Results}

Physical and chemical conditions

During the study period from 11 September to 12 November, the surface water temperature in the lagoon decreased gradually from $22.4^{\circ} \mathrm{C}$ to $12.2^{\circ} \mathrm{C}$ (Table 1). The salinity varied between 35.0 and 38.8 with the lowest values at the end of the period (Table 1). On the last day, the concentrations of ammonium $\left(\mathrm{NH}_{4}{ }^{+}\right)$and nitrate $\left(\mathrm{NO}_{3}{ }^{-}\right)$were very high (4.41 and $5.88 \mu \mathrm{mol} \mathrm{L^{-1 }}$, respectively), whereas lower values between 0.1 and $1.5 \mu \mathrm{mol} \mathrm{L}^{-1}$ were recorded on the previous days (Table 1). From occasional measurements, phosphate concentrations varied from 0.18 to $0.47 \mu \mathrm{mol} \mathrm{L^{-1 }}$ before and during the flood event. The daily amount of solar radiation recorded on the sampling dates was a minimum $\left(300{\mathrm{~J} . \mathrm{cm}^{-2}}^{-2}\right.$ and a maximum $\left(1561{\mathrm{~J} . \mathrm{cm}^{-2}}^{-2}\right.$ for values recorded during the first three weeks of the sampling period (Table 1). 
Phytoplankton dynamics

High concentrations of phytoplankton biomass (Chl a concentration) and high primary production rates (PP) were observed on two occasions (11 September and 16 October) during the

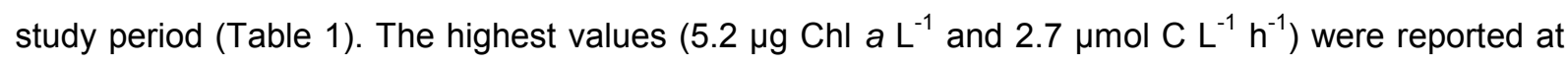
the highest water temperatures when the phytoplankton community was dominated by dinoflagellates (Fig. 2).The lowest PP $\left(0.17 \mu \mathrm{mol} \mathrm{C} \mathrm{L}^{-1} \mathrm{~h}^{-1}\right)$ was measured at the lowest water temperature (30 October). On this date, the phytoplankton biomass and abundance were very low (Table 1) and the community was mainly composed of crytophytes (Fig. 2). PP was positively correlated with cryptophyte (allo, $p<0.01)$, green flagellate" (Chl $b, p<0.01)$, and dinoflagellate (peri, $p<0.01)$ pigment markers (Table 2). The concentrations of particulate organic carbon and nitrogen were generally correlated with the $\mathrm{Chl} \mathrm{a} \mathrm{(Table} \mathrm{1)} \mathrm{and} \mathrm{were} \mathrm{strongly} \mathrm{positively} \mathrm{correlated} \mathrm{with} \mathrm{the} \mathrm{diatom} \mathrm{pigment}$ marker (fuco, $p<0.01$ ) (Table 2), with a $\mathrm{C}: \mathrm{N}$ ratio varying from 3 to 5 . The lowest ratios were recorded when the Chl a was below $1 \mu \mathrm{g} \mathrm{L}^{-1}$.

Heterotrophic bacterial dynamics

Heterotrophic bacterial cell abundance varied between 2.8 and $7.4 \times 10^{6} \mathrm{cell} \mathrm{mL}^{-1}$ and bacterial production rates $(B P)$ varied between 1.6 and $3.7 \mu \mathrm{mol} \mathrm{C} \mathrm{L} \mathrm{L}^{-1} \mathrm{~h}^{-1}$. However, no clear pattern was observed for these two variables during the study period. BP was only $11 \%$ of PP on 7 and 16 October. BP was $32 \%$ and over $50 \%$ of PP on the last two sampling days (30 October and 12 November). On these days, the fraction of BP supported by the freshly produced phytoplankton exudates was the lowest with a value of around $25 \%$ (Table 3 ).

Phytoplankton and bacterial nitrogen uptake rates

The total microbial (phytoplankton + bacteria) $\mathrm{NH}_{4}{ }^{+}$uptake rates $\left(0.05-0.12 \mu \mathrm{mol} \mathrm{N} \mathrm{L}{ }^{-1} \mathrm{~h}^{-1}\right.$ ) were generally higher than the total microbial $\mathrm{NO}_{3}^{-}$uptake rates $\left(<0.05 \mu \mathrm{mol} \mathrm{N} \mathrm{L}{ }^{-1} \mathrm{~h}^{-1}\right)$ except on the first sampling date (11 September). The contribution of the phytoplankton community to the total 
microbial $\mathrm{N}$ uptake rates was estimated from the rates measured using prokaryotic inhibitors and the difference between the rates measured without inhibitors and with the eukaryote inhibitor. This estimate of the phytoplankton contribution excluded the cyanobacterial community, which was assumed to be negligible given their low abundance and low pigment marker concentration (Fig. 2, Table 1). The contribution of the total heterotrophic bacterial community to the total microbial $\mathrm{N}$ uptake rates was estimated from the rates measured using the eukaryotic inhibitor and the difference of rates measured without inhibitors and with prokaryote inhibitors. This estimate included the uptake by cyanobacteria. However, the cyanobacteria abundance was low $\left(0.9 \times 10^{4}\right.$ cell $\mathrm{mL}^{-1}$ on average $)$ compared to free-living bacteria abundance $\left(4.9 \times 10^{6}\right.$ cell $\mathrm{mL}^{-1}$ on average) (Table 1). The contribution of the free-living heterotrophic bacterial community to the total microbial $\mathrm{N}$ uptake rates was estimated from the ${ }^{15} \mathrm{~N}$ measurements performed on precombusted GF/F filters in the fraction less than $0.8 \mu \mathrm{m}(\mathrm{BACT}<0.8)$. The abundance of free-living heterotrophic bacteria $(<0.8 \mu \mathrm{m})$ represented on average $84 \%$ of the total heterotrophic bacteria measured by flow cytometry before size fractionation, but half of these $<0.8 \mu \mathrm{m}$ cells passed through precombusted GF/F filters. Therefore, the abundance of free-living heterotrophic bacteria $(<0.8 \mu \mathrm{m})$ retained on the precombusted GFF/ filters represented about $40 \%$ of the total heterotrophic bacteria cells detected by flow cytometry. Picoeukaryotes and cyanobacteria cells accounted for less than $10 \%$ of the free-living heterotrophic bacteria cells $(<0.8 \mu \mathrm{m})$ retained on precombusted GF/F filters.

The contribution of the phytoplankton community to the total microbial $\mathrm{NO}_{3}^{-}$and $\mathrm{NH}_{4}{ }^{+}$uptake rates was generally higher than the bacterial contribution, averaging $60 \pm 14 \%$. The phytoplankton $\mathrm{NO}_{3}{ }^{-}$ uptake rates were positively correlated with cryptophyte $(p<0.01$.$) , green flagellate" (p<0.01)$ and dinoflagellate $(p<0.01)$ pigment markers, while there was no correlation between the phytoplankton $\mathrm{NH}_{4}{ }^{+}$uptake rates and the concentrations of the phytoplankton pigment markers (Table 2).

The contribution of the total heterotrophic bacteria to the total microbial $\mathrm{NO}_{3}{ }^{-}$and $\mathrm{NH}_{4}{ }^{+}$uptake rates varied between $14 \%$ and $60 \%$ and the $N$ uptake rates by free-living bacteria ( $<0.8 \mu \mathrm{m}$ fraction) accounted for $67 \pm 24 \%$ of the total heterotrophic bacterial contribution. The contribution of free-living bacteria to the total microbial $\mathrm{NH}_{4}{ }^{+}$and $\mathrm{NO}_{3}{ }^{-}$uptake rate tended to be negatively correlated with $\mathrm{Chl} a$ concentrations, the highest contributions (>30\%) being recorded when the $\mathrm{Chl}$ a concentration was low $\left(<2 \mu \mathrm{g} \mathrm{L}{ }^{-1}\right.$, Fig. 4). At these low $\mathrm{Chl}$ a concentrations, the $\mathrm{NO}_{3}{ }^{-}$and $\mathrm{NH}_{4}{ }^{+}$biomass specific rates of free-living bacteria were always significantly lower than rates estimated for phytoplankton (Fig. 5). BP, 
converted into $\mathrm{N}$ production using a C:N ratio of 5 (see [13]), supported by $\mathrm{NH}_{4}{ }^{+}$and $\mathrm{NO}_{3}{ }^{-}$uptake (i.e. total heterotrophic bacterial $\mathrm{N}$ uptake), varied from $87 \%$ to $362 \%$ and from $1 \%$ to $86 \%$, respectively. The lowest percentages were reported at the end of the study period, when BP was only weakly supported by exudates from PP and a wider number of potential substrates were used for growth (Table 3).

\section{Discussion}

Major role of phytoplankton in microbial $\mathrm{NH}_{4}{ }^{+}$and $\mathrm{NO}_{3}{ }^{-}$uptake

During the study period, the temperature of the surface lagoon waters decreased rapidly by more than $10^{\circ} \mathrm{C}$, that is greater than the daily temperature variations usually observed in autumn in the Thau Lagoon (i.e. about $2^{\circ} \mathrm{C}$ ). The results showed a significant positive correlation between temperature and chlorophyll concentration and PP (Table 2) while nutrient levels and solar light radiation had less effect on chlorophyll concentration and PP. The highest PP was measured at temperatures greater than $22^{\circ} \mathrm{C}$, when dinoflagellates dominated the phytoplankton community pigments. The lowest PP and phytoplankton abundance were measured on 30 October at a seawater temperature below $13^{\circ} \mathrm{C}$, when, according to the pigment marker composition, cryptophytes dominated the phytoplankton community despite the relatively high concentration of $\mathrm{NH}_{4}{ }^{+}$. Based on occasional measurements of phosphate concentrations, nitrogen seemed to be the main limiting nutrient for the microbial community as the DIN:PO ${ }_{4}^{3-}$ ratio ranged between 3 and 6 before the flood event (1 Nov), values that are much lower than the Redfield ratio (16). However, the phosphate concentrations $\left(0.2-0.5 \mu \mathrm{mol} \mathrm{L}^{-1}\right)$ were low relative to the increased DIN concentration $\left(4-10 \mu \mathrm{mol} \mathrm{L}^{-1}\right)$ measured in the surface waters of the Thau Lagoon during the flood period [13]. This suggests that $P$ became the limiting nutrient during and after the flood event, with potential distinct consequences on the balance of $\mathrm{C}$ and $\mathrm{N}$ uptake rates between phytoplankton and bacteria on the last day of the study period only.

$\mathrm{NH}_{4}{ }^{+}$and $\mathrm{NO}_{3}{ }^{-}$uptakes were similar to those observed by Collos et al. [5] at other stations in the Thau Lagoon. $\mathrm{NH}_{4}{ }^{+}$uptake rates were in the upper range of rates reviewed by Harrison [16], illustrating the highly dynamic nature of the microbial communities sampled during our study. 
Phytoplankton was the main consumer of $\mathrm{NO}_{3}{ }^{-}$and $\mathrm{NH}_{4}{ }^{+}$with $60 \%$ of total uptake on average, even under potentially $\mathrm{P}$ limiting nutrient conditions.

Except on 11 September, the phytoplankton community used mainly $\mathrm{NH}_{4}{ }^{+}$as a source of inorganic nitrogen, although the concentrations of both $\mathrm{NH}_{4}{ }^{+}$and $\mathrm{NO}_{3}^{-}$were in the same range throughout the study. The preference for $\mathrm{NH}_{4}{ }^{+}$rather than $\mathrm{NO}_{3}{ }^{-}$is generally assumed to be due to the lower energy requirement for ammonium assimilation [6]. No specific phytoplankton group, inferred from pigment makers, seemed to be correlated with the phytoplankton $\mathrm{NH}_{4}{ }^{+}$uptake, while $\mathrm{NO}_{3}{ }^{-}$uptake was significantly and positively correlated with green flagellates", dinoflagellates and cryptophytes. However, diatoms were probably the main contributors to the production of particulate organic matter (POM) in the surface waters when high POM concentrations were reached during the study period, with the $\mathrm{C}: \mathrm{N}$ ratio close to the Redfield ratio. The difference observed between the phytoplankton groups contributing to the $\mathrm{N}$ uptake and biomass tends to suggest that diatoms may use other sources of $\mathrm{N}$ such as organic forms (e.g. amino acids), as reported for several coastal species [8]. Interestingly, zeaxanhtin was positively correlated with $\mathrm{NH}_{4}{ }^{+}$and $\mathrm{NO}_{3}{ }^{-}$concentrations but not with uptake. This suggests that in periods such as those characterized by large inputs of $\mathrm{NH}_{4}{ }^{+}$and $\mathrm{NO}_{3}{ }^{-}$ during a flood event, zeaxanthin may be mainly related to the presence of cyanobacteria and/or green flagellates" probably of freshwater origin transported by the flood.

The role of phytoplankton as the main consumer of DIN suggests that primary producers are likely to outcompete heterotrophic bacteria for DIN in these autumnal coastal waters even when the phytoplankton is adversely affected by the reduction in water temperature. This is confirmed by the biomass specific $\mathrm{NO}_{3}{ }^{-}$and $\mathrm{NH}_{4}{ }^{+}$uptake rates estimated for phytoplankton which are significantly higher than those estimated for free-living bacteria in low chlorophyll waters, i.e. $<2 \mu \mathrm{g} \mathrm{Chl} \mathrm{a} \mathrm{L^{-1 }}$ (Fig. 5). This may be explained by the very high biomass specific carbon production of small picoeukaryote cells previously measured in this coastal lagoon [9] which were dominated by the small picoeukaryote Ostreococcus tauri (-green flagellate" pigment markers) throughout the year [36]. 
High contribution of free-living heterotrophic bacteria to total DIN uptake

The contribution of free-living heterotrophic bacteria (accounting for about $70 \%$ of the total bacterial $\mathrm{N}$ uptake) to the total microbial $\mathrm{NH}_{4}{ }^{+}$and $\mathrm{NO}_{3}{ }^{-}$uptake rates was greater than $30 \%$, when $\mathrm{Chl}$ a was very low (Fig. 4). This supports previous observations performed in other geographical areas showing that heterotrophic bacteria play a greater role in total microbial nitrogen assimilation when phytoplankton biomass is low and algal growth is limited, such as in the Thames estuary [23], Menai Strait [30], Randers Fjord [37], Hong Kong coastal waters [41] and in Arctic coastal waters [10]. All these results suggested that heterotrophic bacteria may outcompete phytoplankton for DIN, indicating that they may have a significant role in DIN utilisation when phytoplankton growth is limited. However, the hypothesis that heterotrophic bacteria outcompete primary producers for DIN in low chlorophyll waters was not confirmed in this study due to the high DIN concentrations and the lower biomass specific DIN uptake rates for free-living heterotrophic bacteria.

Therefore, the apparent high contribution of heterotrophic bacteria to total DIN uptake rates seemed related more to the reduction of phytoplankton biomass in unfavourable growth conditions with a subsequent reduction of primary production and DIN uptake. As a consequence, BP did not depend strongly on PP as reflected by the BP:PP ratio, which could exceed $50 \%$, and the reduced contribution of freshly produced phytoplankton exudates to BP (Table 3). The heterotrophic bacterial community may use other sources of organic $C$ when the BP:PP ratio is high (e.g. organic matter discharged during a flood). Our results suggest a weak dependence of heterotrophic bacteria on algal extracellular production, which is to be expected in environments with coastal inputs of DOC [25] and/or in low productive ecosystems [11]. These authors demonstrated that heterotrophic bacteria may use $\mathrm{C}$ sources (released through mortality or terrestrially-derived carbon) other than those freshly produced by phytoplankton. Similarly, the use of $\mathrm{NO}_{3}{ }^{-}$and $\mathrm{NH}_{4}{ }^{+}$by heterotrophic bacteria in low chlorophyll waters does not support the bacterial $\mathrm{N}$ production in the present study. This suggests that in addition to a high heterotrophic bacterial contribution to the overall DIN uptake, organic $\mathrm{N}$ sources may also be used to a considerable extent. It should be expected that, under such conditions, the heterotrophic bacterial community can contribute more to the pool of particulate organic matter than the phytoplankton. This is supported by the lower C:N ratio of particulate organic matter measured in low chlorophyll conditions. 
It is clear that phytoplankton was the main contributor to the total microbial $\mathrm{NO}_{3}{ }^{-}$and $\mathrm{NH}_{4}{ }^{+}$ uptake (60\% on average) in Thau Lagoon in autumn. Free-living heterotrophic bacteria were responsible for a large contribution $(>30 \%)$ to the total $\mathrm{NH}_{4}{ }^{+}$and $\mathrm{NO}_{3}{ }^{-}$uptake when the phytoplankton biomass, and associated $\mathrm{C}$ and $\mathrm{N}$ production, was reduced at the end of autumn. The lower phytoplankton biomass and production observed in the coldest waters may be due to the high filtration by oysters or export through sedimentation [13] after the flash flood event that occurred at the end of the study period. The low biomass specific DIN uptake rates estimated for free-living heterotrophic bacteria did not support their competition superiority for DIN initially hypothesised in low chlorophyll waters. In these conditions, heterotrophic bacteria seemed to rely more on allochthonous $\mathrm{N}$ and $\mathrm{C}$ sources than on autochthonous phytoplankton-derived sources. This supports the apparent low dependence of heterotrophic bacteria upon PP in low chlorophyll marine waters, initially suggested for C fluxes in oligotrophic marine waters [11 12] and also demonstrated in nutrient-rich coastal waters with a high grazing pressure on phytoplankton [14]. Further investigations are requested at different seasons and in a wide range of geographical marine areas in order to confirm these results and extrapolate the conclusions.

\section{Acknowledgements}

This study was part of the RESTHAU project (2007-2010) Impact of river loadings on microbial communities from Thau Lagoon" funded by the national EC2CO program and coordinated by E. Fouilland. A. Trottet received a postdoctoral fellowship from The University of Montpellier II. We would like to thank M. Cantou (SMEL, UM2) for his assistance during sampling, P. Raimbault (LMGEM UMR 6117, Campus de Luminy. Marseilles) for performing the stable isotope analyses and IFREMER Sète for providing us with the solar radiation data. We thank the two reviewers for their constructive and valuable comments, which helped us to improve the manuscript. This project used the facilities of the Mediterranean Center of Marine Ecosystem Experimental Research MEDIMEER funded by UMR 5119 ECOSYM Ecologie des Systèmes Marins Côtiers", CNRS Institute of Ecology and Environment (InEE), University of Montpellier 2, IFR 129 Armand Sabatier, CNRS-GDR2476 Réseaux Trophiques Aquatiques and Région Languedoc-Roussillon. 


\section{References}

1. Berrouard M (2011) Contribution des bactéries hétérotrophes au cycle marin de l'azote dans I'océan Arctique canadien. M. Sc. thesis, University of Laval, Quebec, Canada. pp54.

2. Bell RT (1990) An explanation for the variability in the conversion factor deriving bacterial cell production from incorporation of $\left[{ }^{3} \mathrm{H}\right]$ thymidine. Limnol Oceanogr 35: 910-913.

3. Bradley PB, Lomas MW, Bronk DA (2010) Inorganic and organic nitrogen use by phytoplankton along Chesapeake Bay, measured using a flow cytometric sorting approach. Estuar Coast Shelf Sci 33: 971-984.

4. Chu Y, Salles C, Tournoud M-G, Got PO, Troussellier M, Rodier C, Caro A (2011) Faecal bacterial loads during flood events in Northwestern Mediterranean coastal rivers. J Hydrol 405: 501-511.

5. Collos Y, Vaquer A, Bibent B, Souchu P, Slawyk G, Garcia N (2003) Response of coastal phytoplankton to ammonium and nitrate pulses: seasonal variations of nitrogen uptake and regeneration. Aquat Ecol 37: 227-236.

6. Dortch O, Thompson PA, Harrison PJ (1991) Short-term interaction between nitrate and ammonium uptake in Thalassiosira-pseudonana - effect of preconditioning nitrogen-source and growth-rate. Mar Biol 110(2): 183-193.

7. Dugdale RC, Wilkerson FP (1986) The use of $n-15$ to measure nitrogen uptake in eutrophic oceans - experimental considerations. Limnol Oceanogr 31(4): 673-689.

8. Fisher NS, Cowdell RA (1982) Growth of marine planktonic diatoms on inorganic and organic nitrogen. Mar Biol 72: 147-155.

9. Fouilland E, Descolas-Gros C, Collos Y, Vaquer A, Souchu P, Gasc A, Bibent B, Pons V (2002) Influence of nitrogen enrichment on size-fractionated in vitro carboxylase activities of phytoplankton from Thau Lagoon (Coastal Mediterranean Lagoon, France). J Exp Mar Biol Ecol 275(2): 147-171.

10. Fouilland E, Gosselin M, Rivkin RB, Vasseur C, Mostajir B (2007) Nitrogen uptake by heterotrophic bacteria and phytoplankton in Arctic surface waters. J Plankton Res 29 (4): 369376.

11. Fouilland E, Mostajir B (2010) Revisited phytoplanktonic carbon dependency of heterotrophic bacteria in freshwaters, transitional, coastal and oceanic waters. FEMS Microbiol Ecol 73: 419-429.

12. Fouilland E, Mostajir B (2011) Complementary support for the new ecological concept of bacterial independence' on contemporary phytoplankton production' in oceanic waters. FEMS Microbiol Ecol 78: 206-207.

13. Fouilland E, Trottet A, Bancon-Montigny C, Bouvy M, Le Floc'h E, Gonzalez JL, Hatey E, Mas S, Mostajir B, Nouguier J, Pecqueur D, Rochelle-Newall E, Rodier C, Roques C, Salles C, Tournoud M-G, Vidussi $F(2012)$ Impact of a river flash flood on microbial carbon and nitrogen production in a Mediterranean Lagoon (Thau Lagoon, France). Estuar Coast Shelf Sci 113:192-204.

14. Fouilland E, Tolosa I, Bonnet D, Bouvier C, Bouvier T, Bouvy M, Got P, Le Floc'h E, Mostajir B, Roques C, Sempéré R, Sime-Ngando T, Vidussi F (2014) Bacterial carbon dependence on freshly produced phytoplankton exudtaes under different nutrient availability and grazing pressure conditions in coastal marine waters. FEMS Microbiol Ecol 87: 757-769. 
15. Garland JL, Mills AL (1991) Classification and characterization of heterotrophic microbial communities on the basis of patterns of community-level solecarbon-source utilization. Appl Environ Microb 57 (8): 2351-2359.

16. Harrison WG (1993) Nutrient recycling in production experiments. ICES Mar Sci 197: 149158.

17. Holmes RM, Aminot A, Kérouel R, Bethanie A, Hooher A, Peterson BJ (1999) A simple and precise method for measuring ammonium in marine and freshwater ecosystems. Can $\mathrm{J}$ Aquat Sci 56: 1801-1808.

18. Kirchman DL (Ed.) (2000) Microbial Ecology of the Oceans. Wiley-Liss 542 p.

19. Kirchman DL, Wheeler PA (1998) Uptake of ammonium and nitrate by heterotrophic bacteria and phytoplankton in the sub-Arctic Pacific. Deep-Sea Res Pt I 45: 347-365.

20. Lee S, Fuhrman JA (1987) Relationships between biovolume and biomass of naturally derived marine bacterioplankton. Appl Environ Microb 53: 1298-1303.

21. Mackey MD, Mackey DJ, Higgins HW, Wright SW (1996) CHEMTAX-a program for estimating class abundances from chemical markers: application to HPLC measurements of phytoplankton. Mar Ecol Prog Ser 144: 265-283.

22. Middelburg JJ, Nieuwenhuize J (2000). Uptake of dissolved nitrogen in turbid, tidal estuaries. Mar Ecol Prog Ser 192: 79-88.

23. Middelburg JJ, Nieuwenhuize J (2000). Nitrogen uptake by heterotrophic bacteria and phytoplankton in the nitrate-rich Thames estuary. Mar Ecol Prog Ser 203: 13-21.

24. Montserrat Sala M, Estrada M, Gasol JM (2006) Seasonal changes in the functional diversity of bacterioplankton in contrasting coastal environments of the NW Mediterranean. Aquat Microb Ecol 44: 1-9.

25. Moran XAG, Estrada M, Gasol JM, Pedros-Alio C (2002) Dissolved primary production and the strength of phytoplanktonbacterioplankton coupling in contrasting marine regions. Microb Ecol 44: 217-223.

26. Nayar S, Chou LM (2003) Relative efficiencies of different filters in retaining phytoplankton for pigment and productivity studies. Estuar Coast Shelf Sci 58: 241-248.

27. Neppel L, Desbordes M, Masson JM (1998) Bias introduced in rainfall risk assessment by a rain gauges network. Water Sci Technol 37 (11): 97-104.

28. Pecqueur D, Vidussi F, Fouilland E, Le Floc'h E, Mas S, Roques C, Salles C, Tournoud M-G, Mostajir B (2011) Dynamics of microbial planktonic food web components during a river flash flood in a Mediterranean coastal lagoon. Hydrobiologia 673: 13-27.

29. Plus M, La Jeunesse I, Bouraoui F, Zaldivar J-M, Chapelle A, Lazure P (2006) Modelling water discharged and nitrogen inputs into a Mediterranean lagoon Impact on the primary production. Ecol Model 193: 69-89.

30. Rodrigues RMNV, Williams PJL (2002) Inorganic nitrogen assimilation by picoplankton and whole plankton in a coastal ecosystem. Limnol Oceanogr 47(6): 1608-1616.

31. Smith DC, Azam F (1992) A simple economical method for measuring bacterial protein synthesis rates in seawater using 3H-leucine. Mar Microb Food Webs 6: 107-114.

32. Strickland JDH, Parsons TR (1968) Determination of reactive nitrite. In: A Practical Handbook of Seawater Analysis. Fish Res Board Can Bull 167: 71-75. 
33. Tournoud MG, Payraudeau S, Cernesson F, Salles C (2006) Origins and quantification of nitrogen inputs into a coastal lagoon: application to the Thau Lagoon (France). Ecol Model 193: 9-33.

34. Tréguer P, Le Corre P (1975) Handbook of seawater nutrient analyses. Autoanalyser II Technicon user guide (2nd ed), Université de Bretagne Occidentale, Laboratoire de Chimie marine, Brest, France, pp. $1-110$.

35. Trottet A, Fouilland E, Leboulanger C, Lanouguère E, Bouvy M (2011) Use of inhibitors for coastal bacteria and phytoplankton: application to nitrogen uptake rates. Estuar Coast Shelf Sci 93: 151-159.

36. Vaquer A, Troussellier M, Courties C, Bibent B (1996) Standing stock and dynamics of picophytoplankton in the Thau Lagoon (northwest Mediterranean coast). Limnol Oceanogr 41: $1821-1828$.

37. Veuger B, Middelburg J, Boschker H, Nieuwenhuize J, Rijswijk P, Rochelle- Newall E, Navarro N (2004) Microbial uptake of dissolved organic and inorganic nitrogen in Randers Fjord. Estuar Coast Shelf Sci 61: 507-515.

38. Vidussi F, Marty JC, Chiavérini J (2000) Phytoplankton pigment variations during the transition from spring bloom to oligotrophy in the north-western Mediterranean Sea. Deep-Sea Res 47: $423-445$.

39. Vidussi F, Mostajir B, Fouilland E, Le Floc'h E, Nouguier J, Roques C, Got P, Thibault-Botha D, Bouvier T, Troussellier M (2011) Effects of experimental warming and increased ultraviolet$B$ radiation on the Mediterranean plankton food web. Limnol Oceanogr 56: 206-218.

40. Wheeler PA, Kirchman DL (1986) Utilization of inorganic and organic nitrogen by bacteria in marine systems. Limnol Oceanogr 31: 998-1009.

41. Yuan XC, Glibert PM, Xu J, Liu H, Chen MR, Liu HB, Yin KD, Harrison PJ (2012). Inorganic and organic nitrogen uptake by phytoplankton and bacteria in Hong Kong waters. Estuar Coast 35(1): 325-334.

42. Zapata M, Rodríguez F, Garrido JL (2000). Separation of chlorophylls and carotenoids from marine phytoplankton: a new HPLC method using a reversed phase C8 column and pyridinecontaining mobile phases. Mar Ecol Prog Ser 195: 29-45. 


\section{Figure legends}

Fig. 1 - Sampling location at the Angle Creek in Thau Lagoon (France)

Fig. 2 - Relative abundances as percentages of phytoplankton groups determined from pigment marker analysis during sampling from 11 September to 12 November 2008. The correspondence between the phytoplankton groups and the pigments marker is: Diatoms (fucoxanthin); Cryptophytes (alloxanthin); Cyanobacteria (zeaxanthin); Green flagellates (Chl b); Dinoflagellates (peridinin); Prymnesiophytes (19‘ hexanoyloxyfucoxanthin)

Fig. 3 - Nitrate (A) and ammonium (B) uptake in $\mu \mathrm{mol} \cdot \mathrm{L}^{-1} \cdot \mathrm{h}^{-1}$ (mean, standard deviation) for phytoplankton and heterotrophic bacteria (shaded bar corresponds to the contribution of free-living bacteria of the total bacteria uptake) from 11 September to 12 November 2008.

Fig. 4 - Scatterplot of the relationship between the contribution of free-living heterotrophic bacteria to total microbial $\mathrm{NH}_{4}{ }^{+}$and $\mathrm{NO}_{3}^{-}$uptake rates (expressed in \%, average and SD) versus $\mathrm{Chl}$ a concentrations $\left(\mu \mathrm{g} \cdot \mathrm{L}^{-1}\right)$ from 11 September to 12 November 2008. Concentrations of $\mathrm{NH}_{4}{ }^{+}$and $\mathrm{NO}_{3}{ }^{-}$are plotted in the insert.

Fig. 5 - Box plot distribution of biomass specific uptake rates of $\mathrm{NH}_{4}^{+}$and $\mathrm{NO}_{3}^{-}\left(\mathrm{h}^{-1}\right)$ for phytoplankton and heterotrophic free-living bacteria $(n=9)$ measured in waters with chlorophyll a concentrations below 2 $\mu \mathrm{g}$ chl $a . \mathrm{L}^{-1}$. p-values of the Wilcoxon signed-rank test are displayed. The lowest boundary of the box indicates the 25th percentile, the line within the box marks the median, and the highest boundary of the box indicates the 75th percentile. Whiskers above and below the box indicate the 90th and 10th percentiles, respectively. 


\section{Table Legends}

Table 1 - Physical data (temperature $\left({ }^{\circ} \mathrm{C}\right)$, salinity and solar radiation $\left(\mathrm{J} \mathrm{cm}^{-2}\right)$ ), nitrate and ammonium concentrations $\left(\mu \mathrm{mol} \mathrm{L} \mathrm{L}^{-1}\right.$ ), abundance of microorganisms (nanoplankton, picoeukaryote, cyanobacteria and free-living heterotrophic bacteria) (cell $\left.\mathrm{mL}^{-1}\right)$, concentration of $\mathrm{Chl} a\left(\mu \mathrm{L} \mathrm{L}^{-1}\right)$, and rates of Primary

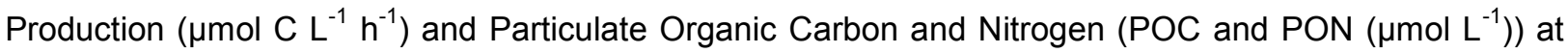
the Creek station from 11 September to 12 November 2008.

Table 2 -Matrix of Spearman Correlations performed between the parameters tested for significance at $p<0.05$ (in grey) and $p<0.01$ (in dark). Temp: temperature, $\mathrm{NH}_{4}$ : ammonium, $\mathrm{NO}_{3}$ : nitrate, $\mathrm{Ab}$ : abundance, Cyano: cyanobacteria, Picoeuk: picoeukaryotes, Nano: nanoplankton, Bact: free-living heterotrophic bacteria, PP: primary production, POC and PON: Particulate organic carbon and nitrogen respectively, fuco: fucoxanthin concentration, allo: alloxanthin concentration, zea :zeaxanthin concentration, $\mathrm{Chl} b$ : chlorophyll b concentration, 19`HF: 19‘ hexanoyloxyfucoxanthin concentration.

Table 3 - Total BP and BP:PP ratio, based on hourly rates, and the fraction (\%) of heterotrophic bacterial $\mathrm{C}$ and $\mathrm{N}$ production supported respectively by freshly produced phytoplanktonic exudates, $\mathrm{NH}_{4}{ }^{+}$uptake and $\mathrm{NO}_{3}{ }^{-}$uptake in samples collected at the Creek station from 7 October to 12 November $2008 .$. 


\section{Table 1}

\begin{tabular}{|c|c|c|c|c|c|c|c|c|c|c|c|c|c|}
\hline Sampling date & Solar radiation & Temp. & Salinity & $\mathrm{NH}_{4}^{+}$ & $\mathrm{NO}_{3}{ }^{-}$ & Cyanobacteria & Picoeukaryote & Nanoplankton & Bacteria & $\begin{array}{l}\text { Phytoplankton } \\
\text { Production }\end{array}$ & Chl a & POC & PON \\
\hline & $\mathrm{J} \mathrm{cm}^{-2}$ & $\left({ }^{\circ} \mathrm{C}\right)$ & & $\mu \mathrm{M}$ & $\mu \mathrm{M}$ & $10^{4}$ cell $\mathrm{mL}^{-1}$ & $10^{4}$ cell $\mathrm{mL}^{-1}$ & $10^{4}$ cell $\mathrm{mL}^{-1}$ & $10^{6}$ cell $\mathrm{mL}^{-1}$ & $\mu \mathrm{mol} \mathrm{C} \mathrm{L}{ }^{-1} h^{1}$ & $\mu \mathrm{g} \mathrm{L}^{-1}$ & $\mu \mathrm{M}$ & $\mu \mathrm{M}$ \\
\hline 11 Sept. & 300 & 22.4 & 36.6 & $0.19(0.01)$ & $1.13(0.21)$ & 0.85 & 2.39 & 0.68 & 5.54 & $2.74(0.03)$ & 5.17 & $81.31(10.36)$ & $16.10(2.15)$ \\
\hline 18 Sept. & 545 & 21.5 & $37 ., 3$ & $0.22(0.03)$ & $0.03(0.01)$ & 2.05 & 4.43 & 0.12 & 2.78 & $0.59(0.03)$ & 1.33 & $46.14(8.48)$ & $12.64(2.03)$ \\
\hline 24 Sept. & 1554 & 18.0 & 38.8 & $0.25(0.01)$ & $0.29(0.01)$ & 0.99 & 1.89 & 0.07 & 4.89 & $0.51(0.10)$ & 0.96 & $42.50(5.90)$ & $12.72(1.73)$ \\
\hline 01 Oct. & 1561 & 17.4 & 38.8 & $0.28(0.06)$ & $0.48(0.01)$ & 0.29 & 0.56 & 0.07 & 4.51 & $0.36(0.02)$ & 0.61 & $41.64(2.65)$ & $11.82(1.32)$ \\
\hline 07 Oct. & 746 & 16.3 & 36.6 & $0.78(0.16)$ & $0.40(0.01)$ & 1.5 & 5.93 & 0.18 & 2.76 & $0.62(0.17)$ & 1.31 & $52.35(5.03)$ & $12.40(1.17)$ \\
\hline 16 Oct. & 989 & 19.3 & 38.4 & $0.23(0.05)$ & $0.22(0.04)$ & 0.8 & 3.02 & 0.11 & 6.37 & $1.37(0.002)$ & 2.47 & $80.96(17.22)$ & $17.35(2.71)$ \\
\hline 20 Oct. & 542 & 17.6 & 38.3 & $1.17(0.21)$ & $0.37(0.01)$ & 0.24 & 1.05 & 0.09 & 5.78 & $0.48(0.01)$ & 1.66 & $47.61(3.48)$ & $12.54(1.69)$ \\
\hline 30 Oct. & 614 & 12.2 & 36.6 & $1.50(0.01)$ & $0.10(0.01)$ & 0.06 & 0.61 & 0.01 & 4.09 & $0.17(0.05)$ & 0.68 & $38.97(3.79)$ & $11.69(0.81)$ \\
\hline 12 Nov. & 377 & 14.8 & 35.0 & $4.41(0.06)$ & $5.85(1.21)$ & 1.14 & 2.98 & 0.18 & 7.45 & $0.37(0.17)$ & 1.66 & $47.08(5.47)$ & $12.65(1.56)$ \\
\hline
\end{tabular}


Table 2

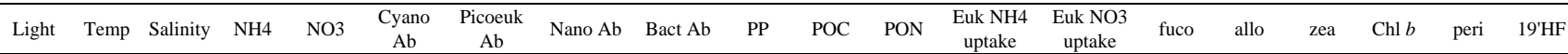

Light

Tem

Salinity

$\mathrm{NO} 3$

Cyano $\mathrm{Ab}$

Picoeuk Ab

Nano Ab

Bact $\mathrm{Ab}$

PP

POC

PON

$-0.06$

$\begin{array}{cccccccc}0.76 & 0.30 & & & & & \\ -0.43 & -0.59 & -0.73 & & & & \\ -0.37 & -0.27 & -0.70 & 0.90 & & & \\ -0.20 & 0.45 & -0.28 & -0.04 & 0.12 & & \\ -0.29 & 0.27 & -0.37 & -0.01 & 0.08 & 0.87 & \\ -0.48 & 0.59 & -0.35 & -0.11 & 0.18 & 0.17 & 0.18 \\ -0.14 & -0.07 & -0.14 & 0.54 & 0.65 & -0.37 & -0.3 \\ -0.32 & 0.70 & -0.07 & -0.35 & -0.06 & 0.09 & 0.13 \\ -0.28 & 0.60 & -0.02 & -0.29 & -0.04 & 0.09 & 0.24 \\ -0.16 & 0.59 & 0.09 & -0.29 & -0.06 & 0.07 & 0.16 \\ -0.54 & 0.39 & -0.13 & 0.05 & 0.08 & 0.22 & 0.34 \\ -0.37 & 0.61 & -0.21 & -0.23 & 0.06 & 0.04 & 0.06 \\ -0.34 & 0.64 & -0.04 & -0.16 & 0.05 & 0.39 & 0.48 \\ -0.43 & 0.28 & -0.34 & -0.03 & 0.14 & -0.11 & 0.05 \\ -0.23 & -0.47 & -0.59 & 0.94 & 0.92 & 0.15 & 0 . \\ -0.59 & 0.70 & -0.19 & -0.30 & -0.12 & 0.30 & 0.41 \\ -0.42 & 0.59 & -0.14 & -0.27 & -0.03 & -0.09 & -0.06 \\ 0.08 & 0.25 & 0.27 & -0.34 & -0.29 & 0.12 & 0.41\end{array}$

.38

0.91

\begin{tabular}{ll}
0.91 & 0.22 \\
\hline & 0.69
\end{tabular}

\begin{tabular}{llll|l|l|}
\hline 16 & 0.54 & 0.43 & 0.82 & 0.97
\end{tabular}

Euk NO3 uptake

fuco

allo

zea

peri

19 'HF

\begin{tabular}{l|l|l|l|l}
0.24 & 0.97 & 0.80 & 0.69 & 0.16
\end{tabular}

\begin{tabular}{lllllll}
0.06 & 0.96 & 0.24 & 0.97 & 0.80 & 0.69 \\
\hline 0.48 & 0.46 & 0.33 & 0.67 & 0.88 & 0.89
\end{tabular}

0.52

\begin{tabular}{l|l|l|l|l|l|l}
0.35 & 0.86 & 0.75 & 0.65 & 0.01 & 0.89 & 0.46
\end{tabular}

0.52

0.85

$\begin{array}{lllllllll}0.54 & -0.41 & -0.30 & -0.26 & 0.00 & -0.32 & -0.08 & -0.17\end{array}$

\begin{tabular}{l|l|l|l|l|l|l|l|l}
0.04 & 0.87 & 0.82 & 0.70 & 0.57 & 0.80 & 0.76 & 0.71 & -0.38
\end{tabular}

\begin{tabular}{lllllllllllll|}
0.22 & 0.94 & 0.74 & 0.62 & 0.23 & 0.97 & 0.45 & 0.87 & -0.40 & 0.82
\end{tabular}

$\begin{array}{lllllllllll}0.08 & 0.30 & 0.66 & 0.68 & 0.35 & 0.10 & 0.73 & 0.16 & -0.26 & 0.41 & 0.04\end{array}$ 
Table 3

\begin{tabular}{|c|c|c|c|c|c|}
\hline & \multicolumn{5}{|c|}{ sampling date } \\
\hline & 7-Oct-08 & $16-$ - $t-08$ & 20-Oct-08 & $30-$-Oct-08 & 12-Nov-08 \\
\hline Bacterial C Production $\left(\mu \mathrm{molC} \mathrm{L}^{-1} \mathrm{~h}^{-1}\right)$ & 0.07 & 0.15 & 0.07 & 0.09 & 0.12 \\
\hline Ratio of BP:PP (\%) & 11 & 11 & 14 & 53 & 32 \\
\hline Fraction of bacterial $\mathrm{C}$ production supported by freshly produced phytoplanctonic exudates $(\%)$ & 109 & 50 & 36 & 7 & 23 \\
\hline Fraction of bacterial $\mathrm{N}$ production supported by $\mathrm{NH}_{4}^{+}$uptake $(\%)$ & 362 & 142 & 211 & 87 & 89 \\
\hline Fraction of bacterial $\mathrm{N}$ production supported by $\mathrm{NO}_{3}^{-}$uptake $(\%)$ & 86 & 56 & 4 & 1 & 36 \\
\hline
\end{tabular}




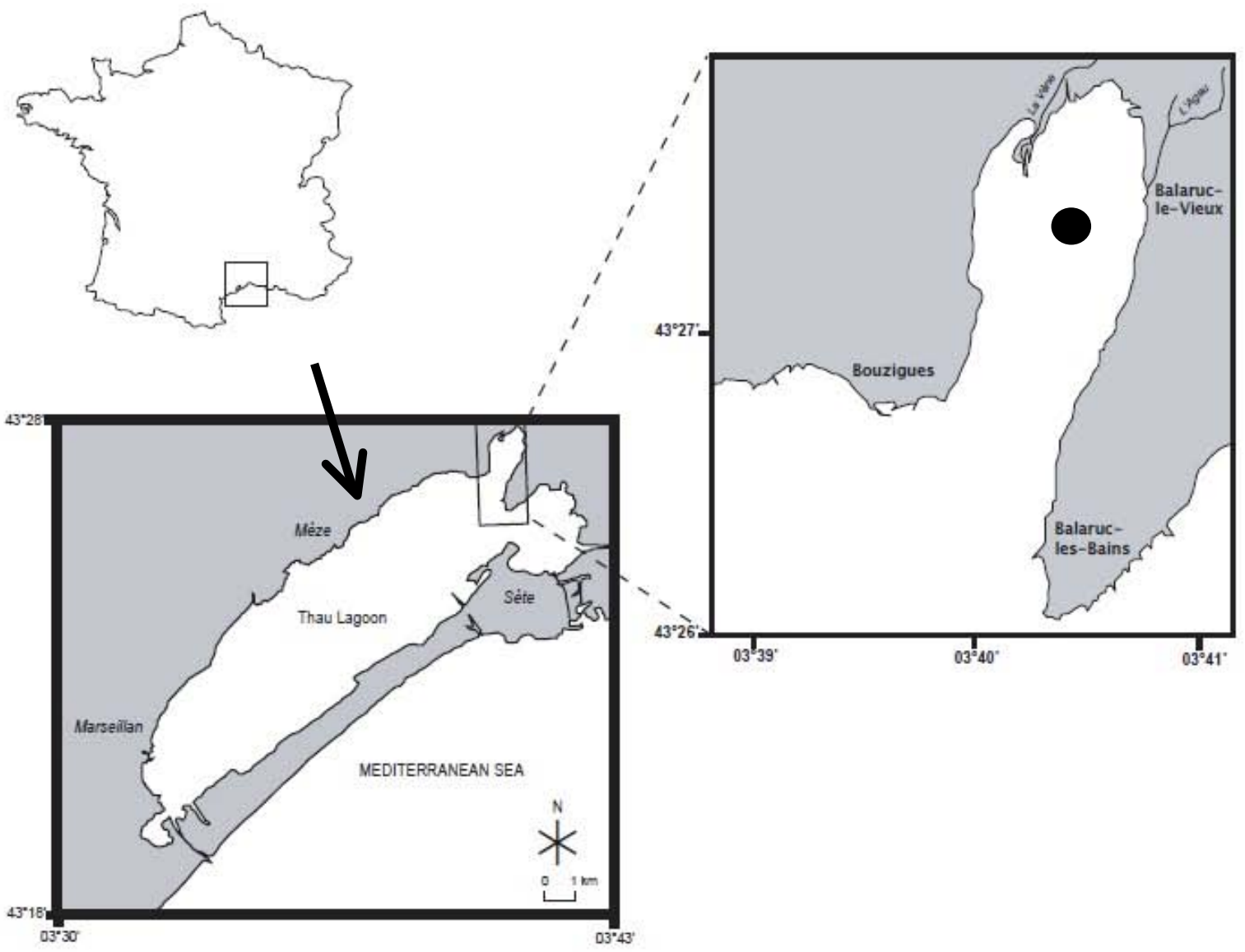

Sampling station

Fig. 1-

Figure 1 


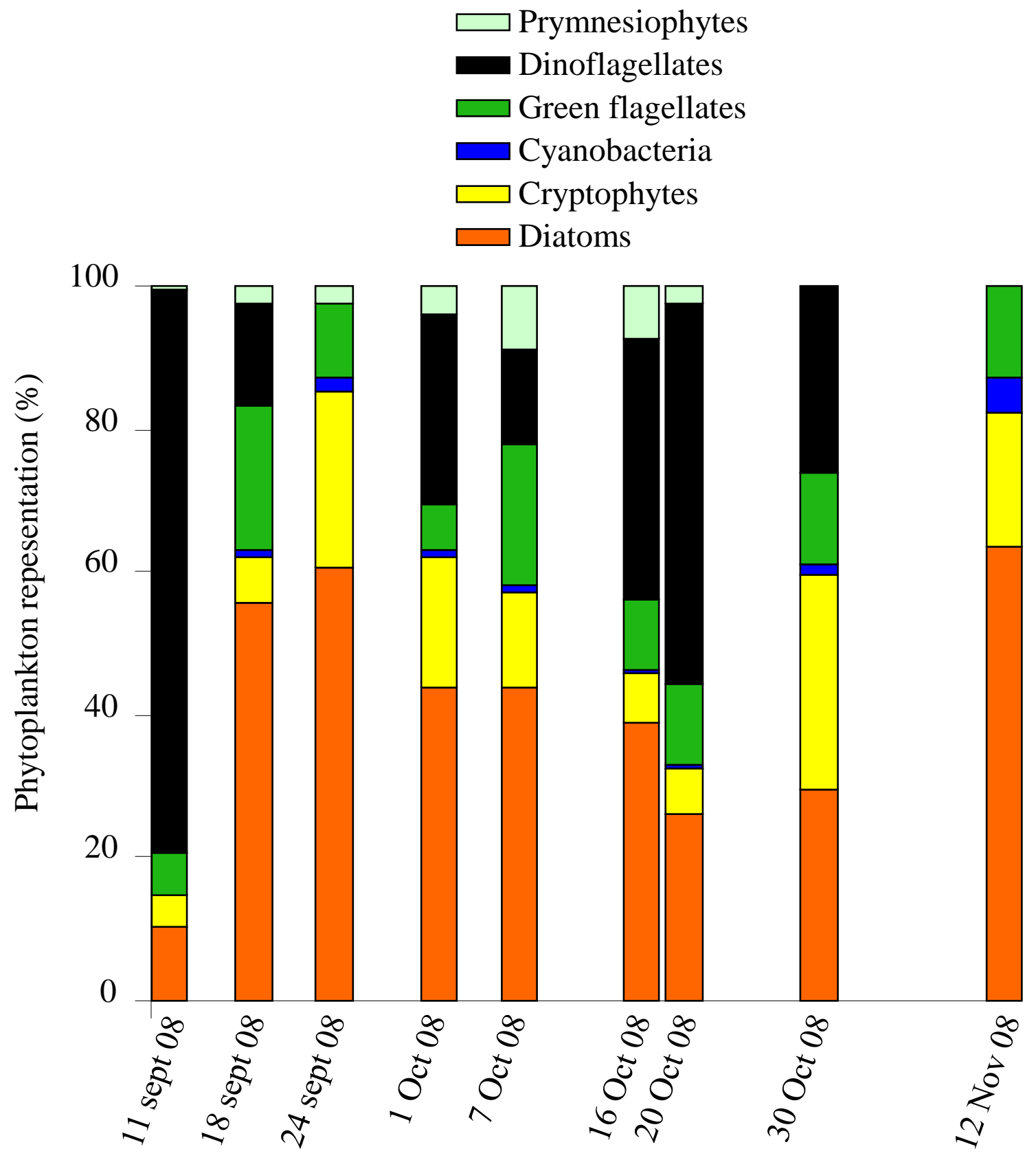

Figure 2 
(A)

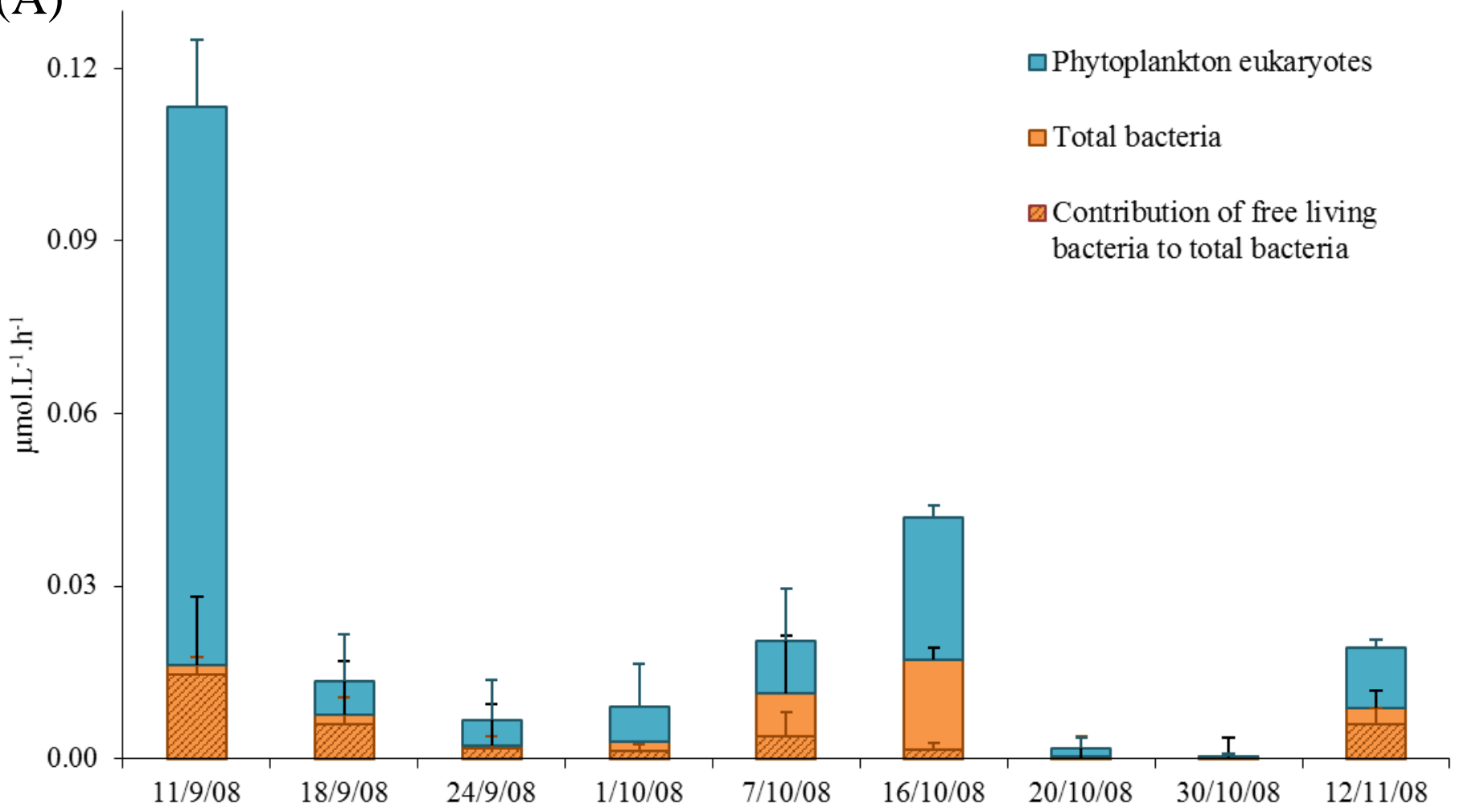

(B)

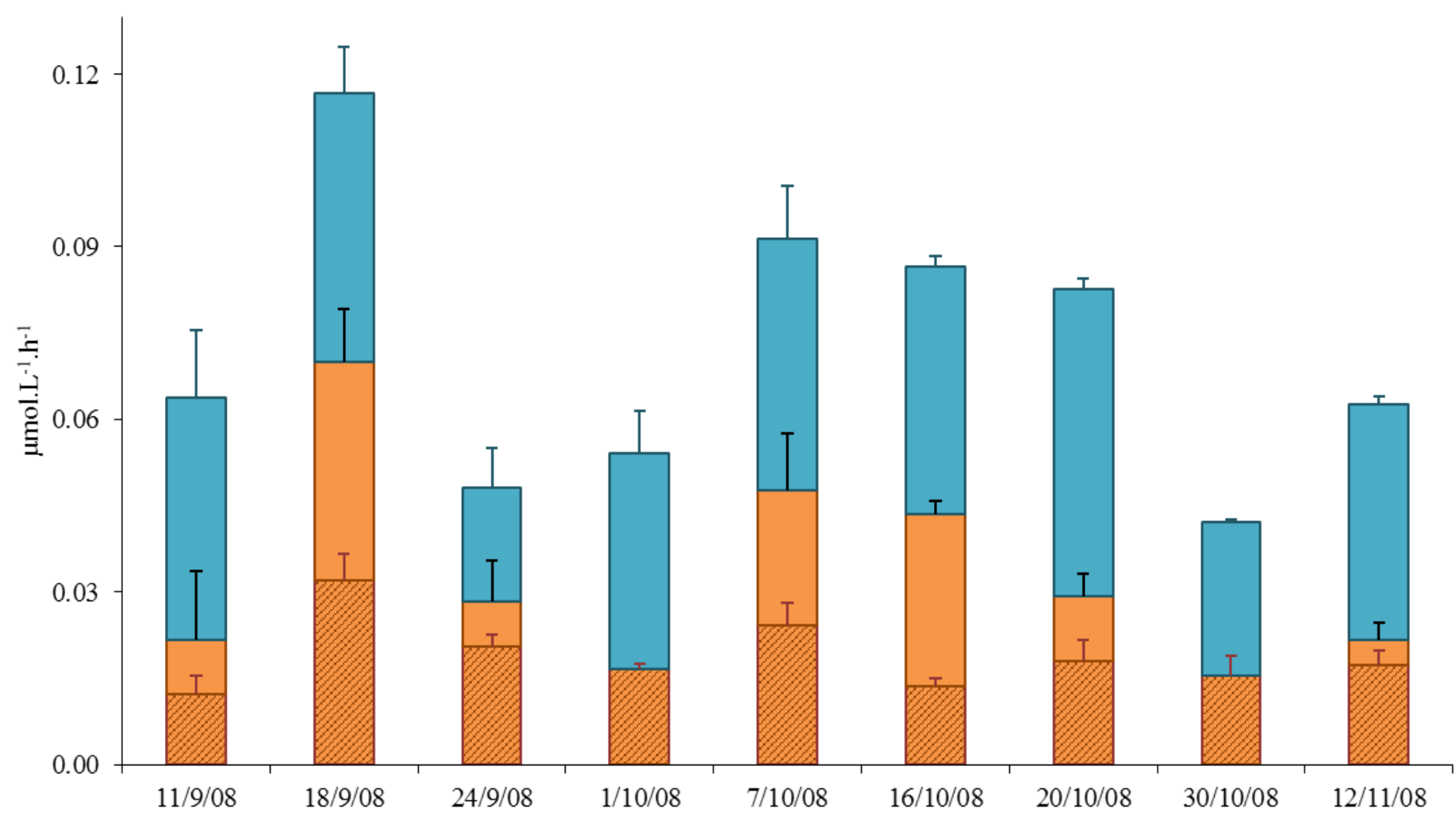

Figure 3 


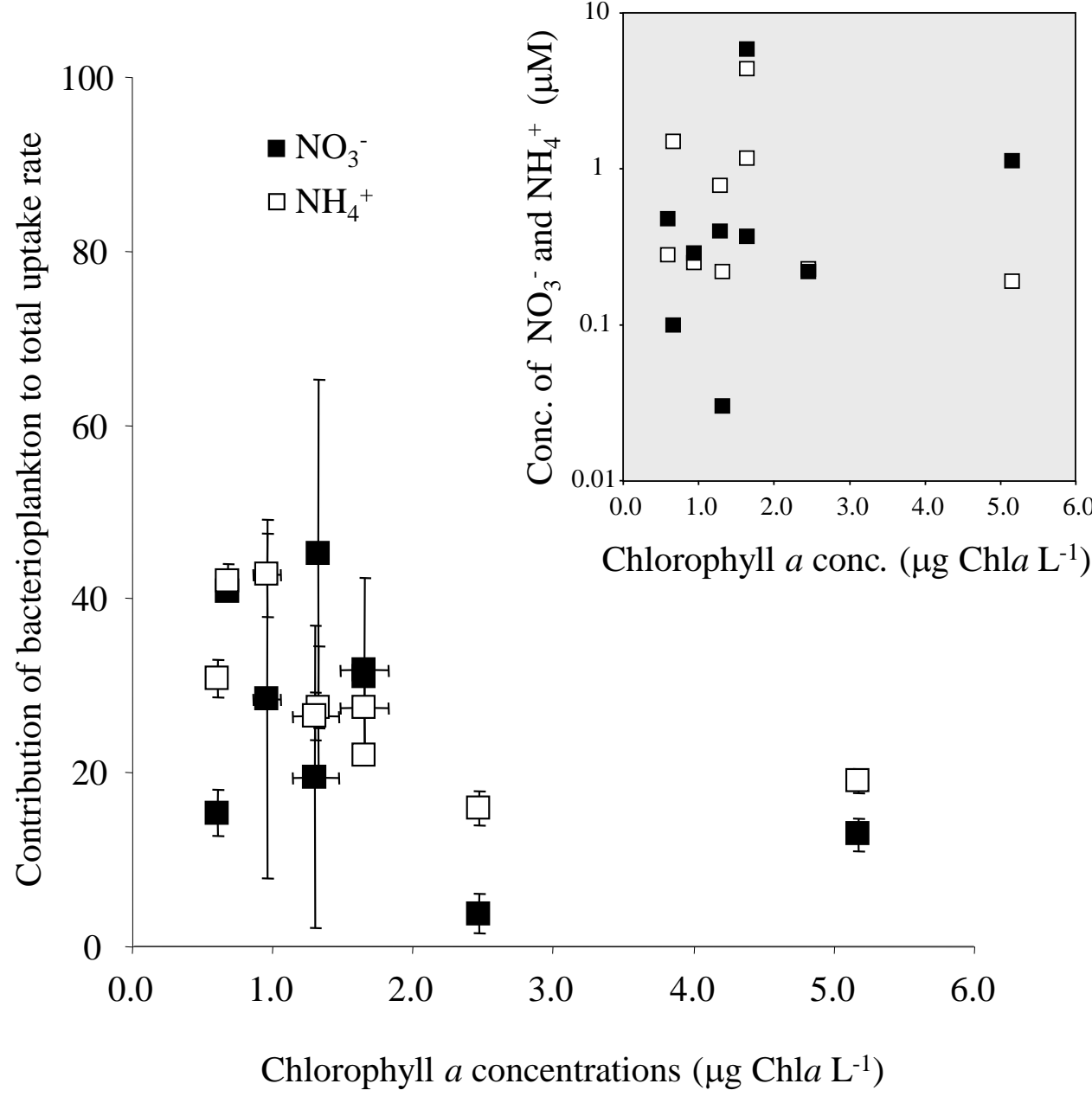

Figure 4 
$\square$ Phytoplankton

Free living heterotrophic bacteria

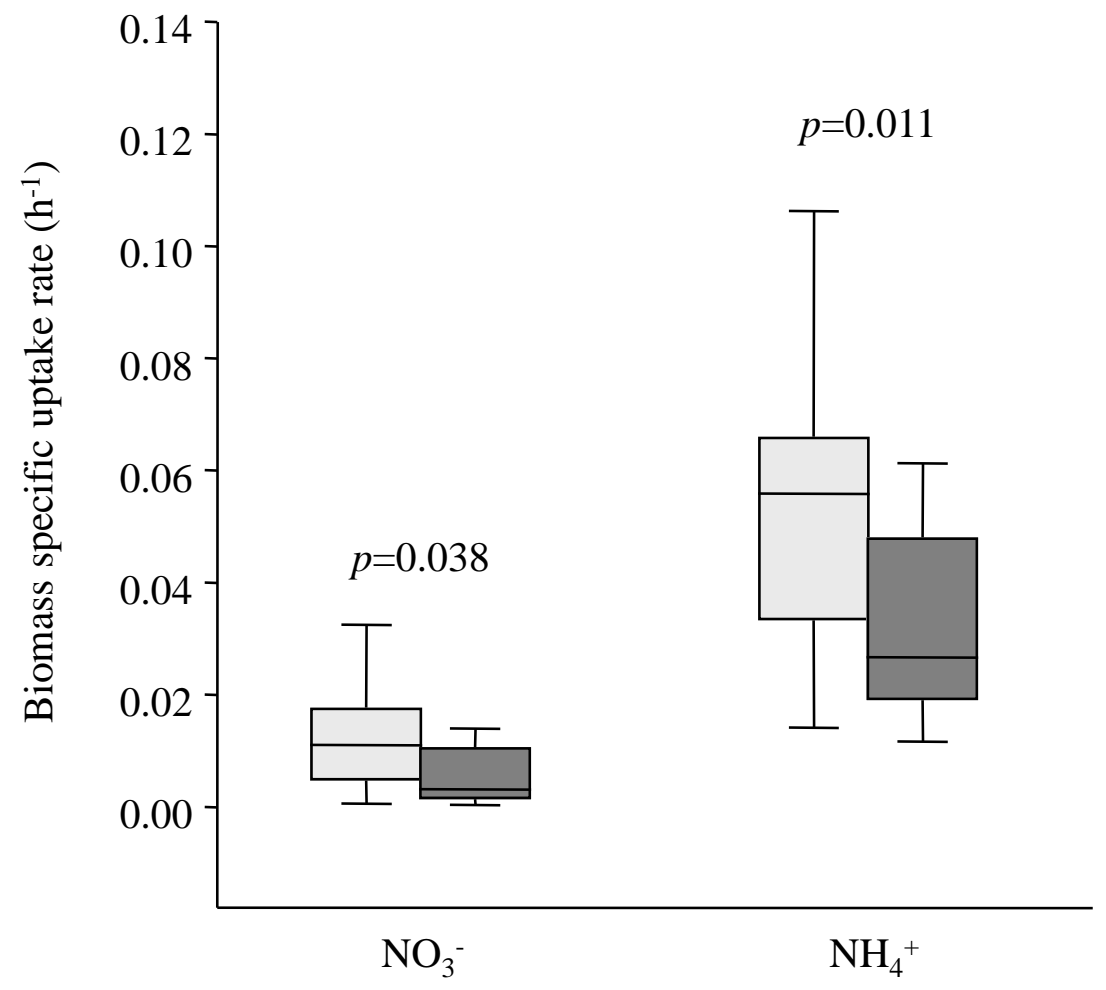

Figure 5 